\title{
Effects of stocking density on growth performance, survival rate, and haematological parameters in rainbow trout (Oncorhynchus mykiss) fingerlings
}

\author{
Soheil Eagderi*1, Mohammad Rahimi ${ }^{2}$, Narger Rostamian ${ }^{3}$ and Syed Abdol Habibi ${ }^{4}$ \\ ${ }^{1}$ Department of Fisheries, Faculty of Natural Resources, University of Tehran, Karaj, Iran; \\ ${ }^{2}$ Department of Fisheries, khoramshar University of Marian science and technology, Khoramshar, Iran; \\ ${ }^{3}$ University of Environment, Faculty of environmental Science, Karaj, Iran; ${ }^{4}$ Department of Aquatic Animal Health, \\ Faculty of Veterinary Medicine, University of Tehran, P.O. Box: 14155-6453, Tehran, Iran
}

\begin{tabular}{|l|l|}
$\begin{array}{l}\text { Article history } \\
\text { Received: 29 Nov, 2015 } \\
\text { Revised: 14 May, 2016 } \\
\text { Accepted: 18 May, 2016 }\end{array}$ & $\begin{array}{l}\text { Abstract } \\
\text { The present study evaluated the effects of stocking density on growth performance, } \\
\text { survival rate, and haematological parameters rainbow trout (Oncorhynchus mykiss) } \\
\text { fingerlings. An experiment was conducted for } 8 \text { weeks with different stocking } \\
\text { densities including T1: } 10 \mathrm{~kg} / \mathrm{m}^{3}, \mathrm{~T} 2: 15 \mathrm{~kg} / \mathrm{m}^{3}, \mathrm{~T} 3: 25 \mathrm{~kg} / \mathrm{m}^{3} \text { and T4: } 35 \mathrm{~kg} / \mathrm{m}^{3} \text {. After } \\
8 \text { weeks, the juveniles were randomly sampled and analyzed for growth indices } \\
\text { including weight gain, survival, specific growth rate (SGR), feed conversion rate } \\
\text { (FCR), and condition factor (CF) as well as haematological parameters including } \\
\text { haemoglobin (Hb), haematocrit (Hct), mean crepuscular haematocrit (MCH), mean } \\
\text { crepuscular haematocrit concentration (MCHC), and red blood cells (RBC). } \\
\text { Treatments with higher density showed lower growth rates (SGR and weight gain) } \\
\text { compared to those of lower densities. Highest survival rate was observed in T2 and the } \\
\text { lowest in T4. Based on the results, the stocking density significantly affected Hct, Hb, } \\
\text { and RBC (P<0.05), while MCH and MCHC were not significantly affected (P }<0.05) . \\
\text { The present study demonstrated that there is a significant negative effect of increasing } \\
\text { rearing density on juvenile rainbow trout. Further, it is suggested } 15 \mathrm{~kg} / \mathrm{m}^{3} \text { as an } \\
\text { appropriate stocking density for rainbow trout fingerlings. } \\
\text { Keywords: Stocking density; growth; haematological parameter; fish }\end{array}$ \\
\hline
\end{tabular}

\footnotetext{
To cite this article: Eagderi S, M Rahimi, N Rostamian and SA Habibi, 2016. Effects of stocking density on growth performance, survival rate, and haematological parameters in rainbow trout (Oncorhynchus mykiss) fingerlings. Res. Opin. Anim. Vet. Sci., 6(4): 115-120.
}

\section{Introduction}

Environmental stressors are important factors limiting fish performance under aquaculture conditions (Pickering, 1992; Wedemeyer, 1997; Ellis et al., 2002). When fish are subjected to adverse environmental conditions, some of their endocrine and physiological properties alter, often resulting in changes the ability of the fish to survive, grow and reproduce (Pickering, 1992; Barton and Iwama, 1991; Trenzado et al., 2008). In intensive fish culture systems, the increasing density is applied to intense the production (Hasanalipour et al., 2013). However, high stocking density has been considered as an aquaculture-related chronic stressor

\footnotetext{
*Corresponding author: Soheil Eagderi, Department of Fisheries, Faculty of Natural Resources, University of Tehran, Karaj, Iran; E-mail: soheil.eagderi@ut.ac.ir
} 
(Vijayan and Leatherhead, 1988; Wedemeyer, 1997; Barton and Iwama, 1991) and poor growth and increasing diseases are often observed at high density. An important factor influencing the growth of fish is the development of hierarchies, mediated by intraspecific competition for food, and this is greatly affected by stocking density (Sirakov and Ivanchev, 2008). Jobling and Baardvik (1994) showed that the manipulation of stocking densities may inhibit or reduce the effects of such hierarchies in Arctic charr, Salvelinus alpinus.

Many works have been focused on evaluating the effects of rearing density on growth (Holm et al., 1990; Bjørnsson, 1994), survival (Hasanalipour et al., 2013), food intake (Jørgensen et al., 1993) and hormonal related changes (EL-Khalid, 2010). Stocking density has been shown to affect behavioural interactions in several fish species (Brown et al., 1992; Christianssen et al., 1992; Irwin et al., 1999; Trenzado et al., 2006) and may ultimately affect growth rates. The effect of stocking density on growth has been reported for a range of cultured fish species such as gilthead seabream, Sparus aurata (Montero et al., 1999), juvenile turbot, Scophthalmus maximus (Irwin et al., 1999), rainbow trout Oncorhynchus mykiss (North et al., 2006), Japanese flounder, Paralichthys olivaceus (Sergio et al., 2006), rainbow trout Oncorhynchus mykiss (Trenzado et al., 2008), silver perch Bidyanus bidyanus (Rowland et al., 2006), halibut Hippoglossus hippoglossus (Bjørnsson, 1994), Arctic charr, Salvelinus alpinus (Jørgensen et al., 1993), rainbow trout Oncorhy-nchus mykiss (Zoccarato et al., 1992), and Atlantic salmon Salmo salar (Liu et al., 2014).

Both positive and negative relationships between stocking density (SD) and growth performance have been reported, and the pattern of this interaction appears to be species specific. In addition, intraspecific competition may influence the growth of reared fish (Sirakov and Ivanchev, 2008). This has been supported by observations on a number of aquatic species, including chum salmon Oncorhynchus keta (Davis and Olla, 1987) and freshwater prawns Macrobrachium rosenbergii (Ra'anan and Cohen, 1984). It has also been reported that high stocking density affects some haematological parameters. Though the results of haematological parameters are widely variable and not always conclusive, many authors reported alternations of the haematological parameters as a common effect of fish crowding (Trenzado et al., 2006, 2007). Therefore, this study was conducted to investigate the effect of density on growth performance, survival rate, and haematological indicators in rainbow trout, Oncorhynchus mykiss fingerlings.

\section{Materials and Methods}

\section{Experimental design and procedures}

A total of 12 similar canals $(10 \times 1 \times 1)$ were used as four triplicate treatments with different stocking densities. The stocking densities were $10 \mathrm{~kg} / \mathrm{m}^{3}$ (T1 as control), $15 \mathrm{~kg} / \mathrm{m}^{3}$ (T2), $25 \mathrm{~kg} / \mathrm{m}^{3}$ (T3), and $35 \mathrm{~kg} / \mathrm{m}^{3}$ (T4), respectively. Rainbow trout fingerlings had an average initial weight of $2.1 \pm 0.15 \mathrm{~g}$. Well-water with a flow rate of $30 \mathrm{l} / \mathrm{sec}$, after passing through a spiral channel was divided equally among the 12 rearing canals. Mean recorded $\mathrm{pH}$ and dissolved oxygen (DO), temperature and photoperiod were $7.8,8.5 \mathrm{ppm}, 10-$ $13^{\circ} \mathrm{C}$ and 10L: 14D, respectively, during experiment. Juveniles were fed at a rate of $3-5 \%$ of body weight five times a day $(8,11,13,15$ and $18 \mathrm{hrs})$. Diet formulations and its proximate compositions are shown in Table 1.

\section{Sample collection and growth index}

A total of 30 juveniles were randomly sampled from each canal every ten days. They were anesthetized using $1 \%$ clove powder solution and their weights and lengths were measured by digital scale to the nearest $0.01 \mathrm{~g}$ and a digital calliper to the nearest $1 \mathrm{~mm}$, respectively. At the end of the experiment, the fish of each pond $(n=40)$ were analyzed for growth indices, including weight gain, survival, Specific Growth Rate (SGR), Feed Conversion Rate (FCR), and Condition Factor (CF) based on the following formula (Das and Ray, 1989):

Weight gain $(\mathrm{g})=$ Final weight - Initial weight

$\mathrm{FCR}=$ Dry feed intake / Wet weight gain

$\mathrm{SGR}=100 \times($ Ln final weight - Ln initial weight $) / 56$ days

Survival $(\%)=100 \times($ initial fish number - dead fish number) / initial fish number

$\mathrm{CF}=\left(\mathrm{W} / \mathrm{L}^{3}\right) \times 100$

\section{Haematological analysis}

At the end of the experiment, fish were sampled from each group $(\mathrm{n}=15)$ and anesthetized immediately by MS-222 $(100 \mathrm{mg} / \mathrm{l})$ and then, the blood samples were taken from their heart using a heparinized syringe. The changes in the haematological parameters, including haematocrit, Mean Corpuscular Haemoglobin $(\mathrm{MCH})$, Mean Corpuscular Haemoglobin Concentration (MCHC), White Blood Cells (WBC), and Red Blood Cells (RBC)] were measures based on method of Haghighi (2009). Haemoglobin was measured using a test kit (Pars Azmun CO., Tehran, Iran) with colorimetric method on a spectrophotometer using 540 nm (Haghighi, 2009). 


\section{Statistical analysis}

For statistical analysis, normality of the data was analyzed by one-sample Kolmogorov-Smirnov test. In the case of normal data, two-way ANOVA was used to analyze the data by the use of SPSS statistical software. The data were compared using Duncan's test at a significance level of $5 \%$.

\section{Results}

After 8 weeks of the experiment, treated fish with lower density i.e., 10 and $15 \mathrm{~kg} / \mathrm{m}^{3}$, significantly $(\mathrm{P}<0.05)$ showed greater body weight and SGR but lower FCR than the higher density (Table 2, Figure 1). Greater weight gain was found in T2 $(17.86 \pm 0.4 \mathrm{~g})$ and the lowest weight gain was observed in T4 $(14.3 \pm 1.4 \mathrm{~g})$. The estimated SGR in T2 was significantly $(\mathrm{P}<0.05)$ higher than those in $\mathrm{T} 1, \mathrm{~T} 3$, and $\mathrm{T} 4(\mathrm{P}<0.05)$, although T3 and T4 were not significantly different $(\mathrm{P}>0.05)$. Low FCR was observed in $\mathrm{T} 2$, that was no significantly different from $\mathrm{T} 1$, whereas $\mathrm{T} 2$ showed a significant difference with $\mathrm{T} 3$ and $\mathrm{T} 4$ $(\mathrm{P}<0.05)$. The $\mathrm{CF}$ had no significant difference between treatments $(\mathrm{P}>0.05)$. Highest survival rate was observed in $\mathrm{T} 2$ and the lowest rate in T4. There was a significant difference $(\mathrm{P}>0.05)$ in the survival rates of fingerlings among treatments. Survival rate was significantly $(\mathrm{P}<0.05)$ lower in $\mathrm{T} 4$ compared to the control.

The stocking density had a significant effects on $\mathrm{Hct}, \mathrm{Hb}$, and $\mathrm{RBC} \quad(\mathrm{P}<0.05)$, whereas other haematological parameters i.e., $\mathrm{MCH}$ and $\mathrm{MCHC}$ were not significantly affected $(\mathrm{P}>0.05$; Table 3$)$. Values of $\mathrm{Hb}$, Hct, and erythrocytes in fish with high stocking density i.e. 25 and $35 \mathrm{~kg} / \mathrm{m}^{3}$, were significantly higher than those treatments with low stocking density i.e. 10 and $15 \mathrm{~kg} / \mathrm{m}^{3}$ (Table 3 ).

\section{Discussion}

In this study, the juveniles reared at the higher stocking densities (T3, T4) showed significantly slower growth rates than those treatments with lower stocking densities (T2, T1). The highest growth was recorded in a density of $15 \mathrm{~kg} / \mathrm{m}^{3}$ (T2) with an increased weight of $17.86 \mathrm{~g}$ and the lowest growth in a density of $35 \mathrm{~kg} / \mathrm{m}^{3}$ (T4) with an increased weight of $14.3 \mathrm{~g}$. Growth, feed efficacy and feed consumption of fishes are governed by environmental factors (Brett, 1979). Many authors have suggested that increasing density has a negative effect on growth factors (Zoccarato et al., 1992; Ross and Watten, 1998; Irwin et al., 1999; Montero et al., 1999; Trenzado et al., 2006; Gholipour et al., 2006; Trenzado et al., 2007; Trenzado et al., 2008;) i.e. overcrowding is a common chronic stressor in aquaculture (Zoccarato et al., 1992). High stocking density suppresses growth (Ross and Watten, 1998;
Irwin et al., 1999; Rowland et al., 2006), which has been attributed to several factors such as decreased food consumption. In addition, high stocking density imposes increased energy demands that require fish to cope with metabolic adjustments such as changes of gluconeogenic and glucolytic enzyme activities. Under such a condition, food consumption is reduced and the extra expenditure of energy has to be met by the body reserves, resulting in reduced growth (Trenzado et al., 2007, 2008; Garcia et al., 2007). Also, the negative impact of the stocking density on growth may be due to increased social interactions between individuals. These interactions are led to intraspecific size variation in groups resulting from the suppression of growth of subordinate individuals by larger conspecifics (Yamagishi et al., 1974; Jobling, 1995; Koebele, 1985).

In some works, numbers of fish are reduced as the fish grow to maintain constant biomass stocking densities (Papst et al., 1992); whereas, in this study, numbers of fish were kept constant during the experiment and, therefore, biomass density was allowed to increase due to the growth of the fish and based on the results the maximum biomass was observed in treatment with a density of $15 \mathrm{~kg} / \mathrm{m}^{3}$ (T2). There is also evidence that removing fish may disrupt hierarchies, and the resulting high levels of interactions between individuals following changes in group structure may affect growth rates (Jobling and Baardvik, 1990).

Growth in terms of weight, weight gain and SGR of fingerlings was significantly higher in $\mathrm{T} 2$ where the stocking density was low compared to those of $\mathrm{T} 3$ and T4. The low growth rate of fry and fingerling in treatments $\mathrm{T} 3$ and $\mathrm{T} 4$ appears to be related to higher densities and increased competition for food and space (Haque et al., 1994; Islam et al., 1999; Islam, 2002; Islam et al., 2002; Rahman and Rahman, 2003; Chakraborty and Mirza, 2005).

The FCR values of T2 and T1 were significantly lower than those of T3 and T4, respectively. The FCR values are lower than those reported by Das and Ray (1989), Islam (2002), and Islam et al. (2002). De Silva and Davy (1992) stated that digestibility plays an important role in lowering the FCR value by efficient utilization of food. Digestibility, in turn, depends on daily feeding rate, frequency of feeding, and type of used food (Chiu et al., 1987). However, low FCR value in the treatment $\mathrm{T} 2$ of the present study indicates better food utilization efficiency, despite this values increased with increasing the stocking densities.

The fingerlings had significantly lower survival rate in highest stocking density i.e. T4. The reason for reduced survival rate in this treatment was probably due to higher stocking density of fry as well as competition for food and space. Similar results were obtained by Tripathi et al. (1979), Uddin et al. (1988), Haque et al. (1994), Kohinoor et al. (1994), Rahman and Rahman (2003) and Chakraborty and Mirza (2005). 


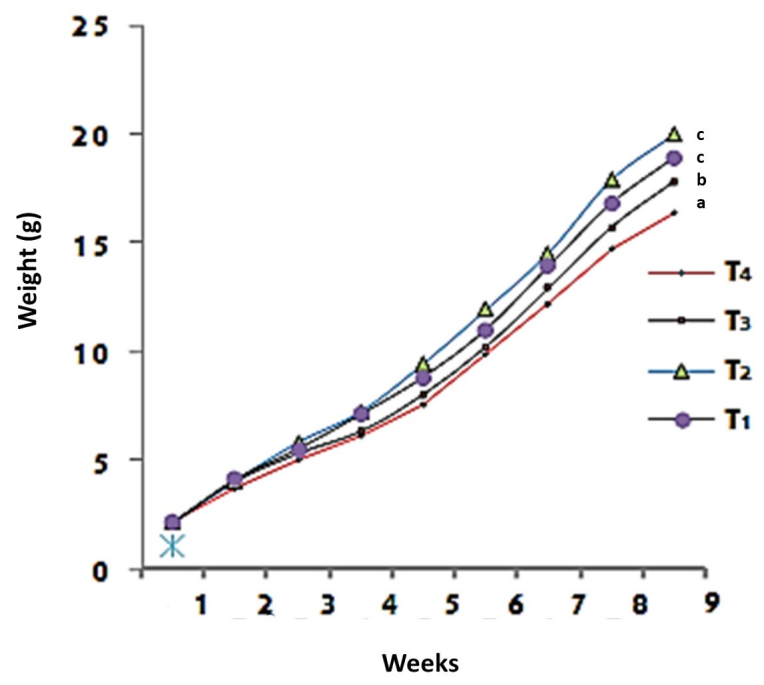

Fig. 1: Changes in the weight of the reared rainbow trout fingerlings at different stocking densities during experiment $\left(\mathrm{T} 1: 10 \mathrm{~kg} / \mathrm{m}^{3}, T 2: 15 \mathrm{~kg} / \mathrm{m}^{3}, \mathrm{~T} 3: 25\right.$ $\mathrm{kg} / \mathrm{m}^{3}$ and $\left.\mathrm{T} 4: 35 \mathrm{~kg} / \mathrm{m}^{3}\right)$.

Table 1: Diet formulations and its proximate compositions

\begin{tabular}{lc}
\hline Ingredient & Amount \\
\hline Fish meal & 58 \\
Wheat flour & 14 \\
Meat flour & 12 \\
Dextrin & 5 \\
Fish oil & 6 \\
Vegetable Oil & 2.2 \\
Filler (sawdust) & 0.8 \\
Mineral mixturec ${ }^{1}$ & 1 \\
Vitamin mixture (vitamin E free) ${ }^{2}$ & 1 \\
Proximate composition (analyzed) & \\
Moistur & $10 \pm 0.8$ \\
Crude protein & $49 \pm 1$ \\
Crude lipid & $15.1 \pm 0.8$ \\
NFE & $16.5 \pm .92$ \\
Energy(Kcal/gr) & 380 \\
\hline
\end{tabular}

Stocking density and growth rates are often reported to be related; however, the relationships between these two may not be uniformly positively or negatively linear for a given species. In some species e.g. Arctic charr (Salvelinus alpinus) however, a positive effect of density on growth is reported (Papst et al., 1992). For example, Baker and Ayles (1990) suggested that growth of Arctic charr increased with stocking density up to a threshold of $40-50 \mathrm{~kg} / \mathrm{m}^{3}$ and then declined at higher densities. Bjornsson (1994) also reported that stocking density affects the growth of halibut (Hippoglossus hippoglossus) only above a certain threshold level corresponding to approximately $100 \%$ coverage of the tank bottom.

It has also been reported that high stocking density affects some haematological parameters. The results are, however, widely variable and not always conclusive. Therefore, interpreting the effect of stocking density on haematocrit is difficult; the haematocrit may have either elevated in T4 compared with the other treatments, possibly indicating an acute stress response (Barton and Iwama, 1991; North et al., 2006) or, alternatively, it may have reduced in T3 as opposed to T2, possibly suggesting anaemia (North et al., 2006). Previous studies have measured the effect of stocking density on haematocrit in rainbow trout (reviewed by Ellis et al., 2002) suggesting higher haematocrit levels in response to increased stocking density (Papst et al., 1992; Wagner et al., 1996). This response may be a strategy for increasing the oxygen carrying capacity of blood under high energy demand situations such as chronic stress (Montero et al., 1999; Trenzado et al., 2006; Trenzado et al., 2008).

In conclusion, the results of the present study demonstrated that there is a significant negative effect of increasing rearing density in juvenile rainbow trout population; increasing densities also resulted in heterogeneous growth rates and the depression of growth of some individuals.

Table 2: Growth performance and survival of rainbow trout fingerlings after 8 weeks of rearing at different densities

\begin{tabular}{lccccc}
\hline Density $\left(\mathrm{kg} / \mathrm{m}^{3}\right)$ & Weight gain $(\mathrm{g})$ & SGR & FCR & CF & Survival (\%) \\
\hline $10 \mathrm{~kg} / \mathrm{m}^{3}(\mathrm{~T} 1)$ & $16.9 \pm 0.5^{\mathrm{c}}$ & $3.44 \pm 0.09^{\mathrm{b}}$ & $1.1 \pm 0.02^{\mathrm{a}}$ & $1.16 \pm 0.14^{\mathrm{a}}$ & $89.6 \pm 2.6^{\mathrm{c}}$ \\
$15 \mathrm{~kg} / \mathrm{m}^{3}(\mathrm{~T} 2)$ & $17.86 \pm 0.4^{\mathrm{c}}$ & $3.78 \pm 0.06^{\mathrm{c}}$ & $1.09 \pm 0.01^{\mathrm{a}}$ & $1.15 \pm 0.12^{\mathrm{a}}$ & $91.2 \pm 4.04^{\mathrm{c}}$ \\
$25 \mathrm{~kg} / \mathrm{m}^{3}(\mathrm{~T} 3)$ & $15.76 \pm 1.1^{\mathrm{b}}$ & $3.28 \pm 0.08^{\mathrm{a}}$ & $1.21 \pm 0.08^{\mathrm{b}}$ & $1.13 \pm 0.14^{\mathrm{a}}$ & $86.8 \pm 3.5^{\mathrm{bc}}$ \\
$35 \mathrm{~kg} / \mathrm{m}^{3}(\mathrm{~T} 4)$ & $14.3 \pm 1.4^{\mathrm{a}}$ & $3.22 \pm 0.04^{\mathrm{a}}$ & $1.32 \pm 0.04^{\mathrm{c}}$ & $1.14 \pm 0.15^{\mathrm{a}}$ & $79 \pm 2.6^{\mathrm{a}}$ \\
\hline The effect of variable & & $0.04^{*}$ & $0.03^{*}$ & 0.26 & $0.00^{*}$ \\
\hline Density & $0.00^{*}$ & ${ }^{*}$ & \\
\hline
\end{tabular}

Table 3: Haematological parameters of rainbow trout fingerlings after 8 weeks of rearing in different stocking densities

\begin{tabular}{|c|c|c|c|c|c|}
\hline $\operatorname{Density}\left(\mathrm{kg} / \mathrm{m}^{3}\right)$ & $\mathrm{MCH}(\mathrm{pg})$ & Hct $(\%)$ & $\mathrm{Hb}(\mathrm{g} / \mathrm{l})$ & $\mathrm{RBC}\left(10^{6} / 1\right)$ & $\operatorname{MCHC}(\mathrm{g} / \mathrm{l})$ \\
\hline $10 \mathrm{~kg} / \mathrm{m}^{3}(\mathrm{~T} 1)$ & $97.1 \pm 3.6^{\mathrm{a}}$ & $29.73 \pm 6.8^{\mathrm{a}}$ & $6 \pm 0.36^{\mathrm{a}}$ & $0.51 \pm 0.06^{\mathrm{a}}$ & $18.1 \pm 1.87^{\mathrm{a}}$ \\
\hline $15 \mathrm{~kg} / \mathrm{m}^{3}(\mathrm{~T} 2)$ & $98.1 \pm 8.9^{\mathrm{a}}$ & $36.5 \pm 4.7^{\mathrm{ab}}$ & $6.23 \pm 0.3^{\mathrm{ab}}$ & $0.65 \pm 0.06^{b}$ & $18.25 \pm 1.7^{\mathrm{a}}$ \\
\hline $25 \mathrm{~kg} / \mathrm{m}^{3}(\mathrm{~T} 3)$ & $100.7 \pm 6.9^{a}$ & $34.9 \pm 5.7^{\mathrm{ab}}$ & $6.9 \pm 0.4^{b c}$ & $0.69 \pm 0.1^{\mathrm{b}}$ & $18.3 \pm 1.6^{\mathrm{a}}$ \\
\hline $35 \mathrm{~kg} / \mathrm{m}^{3}(\mathrm{~T} 4)$ & $100.9 \pm 5.4^{\mathrm{a}}$ & $41.33 \pm 6.1^{\mathrm{b}}$ & $7.5 \pm 0.3^{\mathrm{c}}$ & $0.73 \pm 0.1^{\mathrm{c}}$ & $17.6 \pm 1.8^{\mathrm{a}}$ \\
\hline \multicolumn{6}{|c|}{ The effect of variable } \\
\hline Density & 0.29 & $0.01^{*}$ & $0.014^{*}$ & $0.00^{*}$ & 0.86 \\
\hline
\end{tabular}




\section{Acknowledgments}

The kind assistance of the management of Tehran Ghezel Ala Co. is appreciated.

\section{References}

Baker RF, Ayles GB (1990) The effects of varying density and loading level on the growth of Arctic charr Salvelinus alpinus and rainbow trout Oncorhynchus mykiss. World Aquac 21: 58-62.

Barton BA, Iwama GK (1991) Physiological changes in fish from stress in aquaculture with emphasis on the response and effects of corticosteroids. Ann Rev Fish Dis 1: 3-26.

Bjørnsson B (1994) Effects of stocking density on growth rate of Halibut Hippoglossus hippoglossus reared in large circular tanks for three years. Aquaculture 123: 259-270.

Brett JR (1979) Environmental factors and growth. In: Hoar WS, Randall DJ, Brett JR (editors), Fish Physiology. Academic Press, New York, pp: 599675.

Brown GE, Brown JA, Srivastava RK (1992) The effect of stocking density on the behaviour of Arctic charr Salvelinus alpinus L. J Fish Biol 41: 955963.

Chakraborty BK, Mirza MJA (2005) Effect of stocking density on survival and growth of endangered bata, Labeo bata (Hamilton-Buchanan) in nursery ponds. Aquaculture 265: 156-162.

Chiu YN, Sumagaysay NS, Sastrillo MGS (1987) Effect of feeding frequency and feeding rate on the growth and feed efficiency of milk fish, Chanos chaqnos (Forskal) Juveniles. Asian Fish Sci 1: 2731 .

Christianssen JS, Svendsen YS, Jobling M. (1992) The combined effects of stocking density and sustained exercise on the behaviour, food intake and growth of juvenile Arctic charr (Salíelinus alpinus). Can J Zool 70: 115-122.

Das I, Ray AK (1989) Growth performance of Indian major carps Labeo rohita (Ham.) on duckweed incorporate pelleted feed: a preliminary study. J Inland Fish Soc India 21: 1-6.

Davis MW, Olla BL (1987) Aggression and variation in growth of chum salmon (Oncorhynchus keta) juveniles in sea water: effects of limited rations. Can J Fish Aquat Sci 44: 192-197.

De Silva SS, Davy FB (1992) Fish nutrition research system in Asia. Asian Fish Sci 5: 129-144.

EL-Khaldi ATF (2010) Effect of different stress factors on some physiological parameters of Nile tilapia (Oreochromis niloticus). Saudi J Biol Sci 17(3): 241-246.

Ellis T, North B, Scott AP, Bromage NR, Porter M, Gadd D (2002) The relationships between stocking density and welfare in farmed rainbow trout. J Fish Biol 61: 493-531.

Garcia F, Pilarski EM, Onaka FR, Moraes D, Martins ML (2007) Hematology of Piaractus mesopotamicus fed diets supplemented with vitamins C and E, challenged by Aeromonas hydrophila. Aquaculture 271: 39-46.

Gholipour F, Allameh SK., Arani MM, Naser M (2006) Effect of density on growth and feed conversion ratio in rainbow trout (Oncorhynchus mykiss). Pajouhesh Va Sazandegi 70: 23-27. (In Persian).

Haghighi M (2009) Laboratory Methods of Fish Hematology. Iranian Fisheries Research Organization Publication. Iran, Tehran. (In Persian)

Haque MZ, Rahman MA, Hossain MM, Rahman MA (1994) Effect of stocking densities on the growth and survival of mirror carp, Cyprinus carpio var. specularis in rearing ponds. Bangladesh J Zool 22: 109-116.

Hasanalipour A, Eagderi S, Poorbagher H, Bahmani M (2013) Effects of stocking density on blood cortisol, glucose and cholesterol levels of immature Siberian sturgeon (Acipenser baerii Brandt, 1869). Turk J Fish Aquat Sci 13: 01-06.

Holm JC, Refstie T, Bo S (1990) The effect of fish density and feeding regimes on individual growth rate and mortality on rainbow trout (Oncorhynchus mykiss). Aquaculture 89: 225-232.

Irwin S, O'Halloran J. FitzGerald RD (1999) Stocking density, growth and growth variation in juvenile turbot, Scophthalmus maximus (Rafinesque). Aquaculture 178: 77-88.

Islam AKMS, Hossain MMM, Chakraborty BK (1999) Growth performance of mirror carp fry fed on different supplementary diets. Bangladesh $\mathrm{J}$ Train Dev 12: 161-165.

Islam MS, Dewan S, Hussain MG, Hossain MA, Mazid MA (2002) Feed utilization and wastage in semiintensive pond culture of mahseer, Tor putitora (Ham.). Bangladesh J Fish Res 6: 1-9.

Islam MS (2002) Evaluation of supplementary feeds for semiintensive pond culture of Mahaseer, Tor putitora (Hamilton). Aquaculture 212: 263-276.

Jobling M, Baardvik BM (1994) The influence of environmental manipulations on inter- and intraindividual variation in food acquisition and growth performance of Arctic charr, Salvelinus alpinus. J Fish Biol 44: 1069-1087.

Jobling M (1995) Simple indices for the assessment of the influences of social environment on growth performance, exemplified by studies on Arctic charr. Aquacult Int 3: 60-65.

Jørgensen EH, Christiansen JS, Jobling M (1993) Effects of stocking density on food intake, growth performance and oxygen consumption in Arctic charr Salvelinus alpinus. Aquaculture 110: 191-204. 
Koebele BP (1985) Growth and the size hierarchy effect: an experimental assessment of three proposed mechanisms; activity differences, disproportional food acquisition, physiological stress. Environ Biol Fish 12: 181-188.

Kohinoor AHM, Haque MZ, Hussain MG, Gupta MV (1994) Growth and survival of Thai punti, Puntius gonionotus (Bleeker) spawn in nursery ponds at different stocking densities. J Asiatic Soc Bangladesh Sci 20: 65-72.

Liu B, Liu Y, Liu Z, Qiu D, Sun G, Li X (2014) Influence of stocking density on growth, body composition and energy budget of Atlantic salmon Salmo salarL. in recirculating aquaculture systems. Chinese J Oceanol Limnol 32(5): 982-990.

Montero D, Izquierdo MS, Tort L, Robaina L, Vergara JM (1999) High stocking density produces crowding stress altering some physiological and biochemical parameters in gilthead seabream, Sparus aurata, juveniles. Fish Physiol Biochem 20: 53-60.

North BP, Ellis T, Turnbull JF, Davis J, Bromage NR (2006) Stocking density practices of commercial UK rainbow trout farms. Aquaculture 259: 260267.

Papst MH, Dick TA, Arnason AN, Engel CE, (1992) Effect of rearing density on the early growth and variation in growth of juvenile Arctic charr, Salvelinus alpinus L. Aquac Fish Manag 23: 41-47.

Pickering AD (1992) Rainbow trout husbandry: management of the stress response. Aquaculture 100: 125-139.

Ra'anan Z, Cohen D (1984) The effect of group interactions on the development of size distribution in Macrobrachium rosenbergii de Man. juvenile populations. Biol Bull 166: 22-31.

Rahman MR, Rahman MA (2003) Studies on the growth, survival and production of calbasu (Labeo calbaus Ham.) at different stocking densities in primary nursing. Bull Fac Sci Univ Ryukyus JPN 76: 245-255.

Ross RM, Watten BJ, (1998) Importance of rearing-unit design and stocking density to the behavior, growth and metabolism of lake trout (Salvelinus namaycush). Aquaculture Eng 19: 41-56.

Rowland SJ, Mifsud C, Nixon M, Boyd P (2006) Effects of stocking density on the performance of the Australian freshwater silver perch (Bidyanus bidyanus) in cages. Aquaculture 253: 301-308.

Sergio NB, Adriana P, Yamashita Y (2006) Digestive enzymes activity during ontogenetic development and effect of starvation in Japanese flounder, Paralichthys olivaceus. Aquaculture 252: 503-515.
Sirakov I, Ivanchev E (2008) Influence of stocking density on the growth performance of rainbow trout and brown trout grown in recirculation system. Bulg J Agric Sci 14:150-154.

Trenzado EC, Morales AE, la Higuera MD (2006) Physiological effects of crowding in rainbow trout, Oncorhynchus mykiss, selected for low and high stress responsiveness. Aquaculture 258: 583-593.

Trenzado CE, Morales AE, Higuera ML (2007) Influence of dietary vitamin $\mathrm{E}$ and $\mathrm{C}$ and HUFAon in rainbow trout (Oncorhynchus mykiss) performance under crowding condition. Aquaculture 263: 249-258.

Trenzado CE, Morales AE, Higuera ML (2008) Physiological changes in rainbow trout held under crowding condition and fed diets with different levels of vitamin $\mathrm{E}$ and $\mathrm{C}$ and highly unsaturated fatty acids (HUFA). Aquaculture 277: 293-302.

Tripathi SD, Dutta A, Sen Gupta KK, Pattra S (1979) High density rearing of Rohu spawns in village ponds. Symosium of Inland Aquaculture. (Abstracts) February 12-13, 1979, CIFRI. Barrack Pore. 14 pp.

Uddin MS, Gupta MV, Barua G (1988) Effect of fertilizers on the growth and survival of Rohu, (Labeo rohita) spawn in nursery ponds. Bangladesh J Fish Res 11: 83-88.

Vijayan MM., Leatherhead JF (1988) Effect of stocking density on the growth and stress-response in brook charr, Salvelinus fontinalis. Aquaculture 75: 159-170.

Wagner EJ, Intelmann SS, Routledge D (1996) The effects of fry rearing density on hatchery performance, fin condition, and agonistic behaviour of rainbow trout Oncorhynchus mykiss fry. J World Aquac Soc 27: 264-274.

Wedemeyer GA (1997) Effects of rearing conditions on the health and physiological quality of fish in intensive culture. In: Iwama GK, Pickering AD, Sumpter JP, Schreck CB (editors), Fish Stress and Health in Aquaculture. Cambridge University Press, Cambridge, pp: 35-70.

Yamagishi HT, Maruyama T, Mashiko K (1974) Relations in a small population of Odontobutis obscuris Temmack et Schlegel, as related to individual growth and food intake. Oecologia 17: 187-202.

Zoccarato I, Benatti G, Bianchini ML, Boccignone M, Conti A, Palmegiano GB (1992) The effect of density and feeding level on performances and body composition in Oncorhynchus mykiss. In: Barnabe G, Kestemont P (editors), Production, Environment and Quality, Publ. No. 18. European Aquaculture Society, Belgium. 